\title{
Geospatial Analysis of Fluoride Concentration in Groundwater in Puruliya District, West Bengal
}

Juthika Mandal ${ }^{+*}$ and Dr Srabani Sanyal

\section{Abstract}

Fluoride contamination in groundwater is a major geo-environmental issue. In India, groundwater sources contribute more than 85 per cent of the drinking water requirement in rural areas, 76 per cent of irrigation requirements and more than 50 per cent of the urban and industrial water supplies. Many studies have reported fluoride-related health problems such as dental and skeletal fluorosis in humans due to drinking of fluoride-rich water which has severe socio-economic implications. The permissible limit of fluoride in drinking water is $1.5 \mathrm{mg} / \mathrm{l}$ according to the World Health Organisation (WHO, 2004) and the Bureau of Indian Standards (BIS, 2012).

Puruliya is the westernmost district of West Bengal and located on the eastern slope of the Chotanagpur plateau. The intensive and prolonged dry spell, semi-arid climate, long-term withdrawal of groundwater for irrigation, alkaline nature of sub-surface circulating water, a long residence time of water in fractured aquifers and low chances of dilution are favourable for fluoride enrichment in the Puruliya District. Eighteen out of 20 blocks of the district have high fluoride level in groundwater. This paper attempts to examine the status of fluoride concentration in groundwater, its distribution including the causative factors for its occurrence. It also tries to draw a comparative view of the change in fluoride pattern for the period 2005-06 and 2015-16 and estimate population under threat. Data collected from Physical Health \& Engineering Department (PHED) is superimposed over topographical maps and Google Earth. Mapping of fluoride endemic areas in Puruliya district is attempted to delineate areas and the extent of fluoride contamination in the study area.

Keywords: Fluoride, Groundwater Contamination, Geospatial Analysis, Puruliya District, West Bengal, India

\footnotetext{
+ Ms. Juthika Mandal, Research Scholar, Department of Geography, Institute of Science, Banaras Hindu University, Varanasi-221005

${ }^{*}$ Corresponding Author, Email: juthikamandal2012@gmail.com

i Associate Professor, Department of Geography, Institute of Science, Banaras Hindu University, Varanasi-221005, Email: srabani72@gmail.com

(C) 2019 Mandal and Sanyal. This is an Open Access article distributed under the terms of the Creative Commons Attribution License (http://creativecommons.org/licenses/by/2.0), which permits unrestricted use, distribution, and reproduction in any medium, provided the original work is properly cited.
} 


\section{Introduction}

The central objective of this research is to evaluate the concentration of fluoride in groundwater in the Puruliya District, West Bengal using GIS technology. At first, though it is important to shed a brief outline on the groundwater background of the country.

India is the largest consumer of groundwater in the world (World Bank, 2010). It contributes more than 85 per cent of the drinking water requirement in rural areas, 76 per cent of irrigation requirements and more than 50 per cent of the urban and industrial water supplies (Secretariat, 2016). It is reported that the total annual replenishable groundwater resources of the country are $433 \mathrm{BCM}$ and the net annual groundwater availability is $398 \mathrm{BCM}$. Out of the total annual groundwater draft of 245 BCM, the share of groundwater being utilised for irrigation and industrial and domestic sectors is 222.36 BCM (90.75\%) and 22.71 BCM (9.26\%), respectively (CGWB, 2011). However, during the last five decades the groundwater is being exploited due to overextraction leading to deterioration of quality beyond sustainable levels. According to the Central Pollution Control Board of India, a vast majority of groundwater quality problems are caused by contamination, over-exploitation, or a combination of the two. Rainfall contributes around 68 per cent of groundwater recharge in India, however, only $3 \%$ area of the country receives excess; $67 \%$ receives normal water recharge and the remaining $30 \%$ of the area receives deficient rainfall. Evidently, almost the whole country is showing a decline in the water level; the maximum fall is observed in and around the parts of Rajasthan, Haryana, Punjab, Gujarat, Telangana, and Maharashtra. To be more specific, in major parts of the country, the water level is observed to be in the range of 5 to $10 \mathrm{~m}$ (CGWB, 2017). Apart from the physical environment, there are various socio-economic and institutional factors which affect the availability and sustainability of the groundwater resource. There is a 15 per cent reduction in per capita availability of groundwater from 2001 to 2011in India due to increase in population (Suhag, 2016). It is also observed that of the 6607 assessment units in the country, 1071 units are fall into the category of 'over exploited' where groundwater development is 100 per cent but extraction exceeds net availability (The Ministry of Water Resources, River Development \& Ganga Rejuvenation, CGWB, 2011). Table 1 provides an overview of the status of groundwater of the whole country for the period 1995-2011.

Other than quantity it is observed that the quality of groundwater is also deteriorating in many parts of the country. Groundwater contamination is reported to be mainly due to Arsenic, Fluoride and other heavy metals such as lead, cadmium, chromium etc. at an alarming rate (Table 2)(CGWB, 2011).

While the major arsenic affected states are Haryana, Punjab, Uttar Pradesh, Bihar, Jharkhand, Chhattisgarh, West Bengal, Assam, Manipur and Karnataka, the states with high fluoride contamination are Andhra Pradesh, Punjab, Haryana, Rajasthan, Gujarat, Tamil Nadu, and Uttar Pradesh (Teotia \& Teotia, 1984; CGWB, 2011). This research aims to examine the fluoride contamination in groundwater in Puruliya district, therefore, the discussion from here on is concentrated on the fluoride.

When fluorine makes a bond with other elements, it is called fluoride. The problem of the high level of fluoride $\left(\mathrm{F}^{-}\right)$in groundwater sources has become one of the critical toxicological and geo-environmental issues in India (Ali et al., 2016). Fluoride is widely available in nature and is estimated to be the 13th most abundant element on our planet (Mason and Moore, 1982). Fluoride is a salt of fluorine and can exist as hydrogen fluoride and calcium fluoride. It forms the lightest member of the halogen group (no.17) in the periodic table which includes chloride, bromide and iodine. Fluorine can form both covalent and electrovalent bonds with other elements, and its extreme electronegativity makes the covalent bonds strongly polar (ATSDR, 2001, Weinstein \& Davison, 2004). 


\begin{tabular}{|c|c|c|c|c|c|c|}
\hline \multicolumn{2}{|c|}{$\begin{array}{l}\text { Level of Groundwater } \\
\text { Development }\end{array}$} & \multicolumn{4}{|c|}{ District in Per cent } & \multirow{2}{*}{$\begin{array}{l}\text { Name of the States } \\
2011\end{array}$} \\
\hline $\begin{array}{l}\text { Range in } \\
\%\end{array}$ & Category & 1995 & 2004 & 2009 & 2011 & \\
\hline $0-70$ & Safe & 92 & 73 & 72 & 71 & $\begin{array}{l}\text { Andhra Pradesh, Arunachal Pradesh, } \\
\text { Bihar, Chhattisgarh, Jammu \& } \\
\text { Kashmir, Jharkhand, Karnataka, } \\
\text { Kerala, Madhya Pradesh, } \\
\text { Maharashtra, Manipur, Meghalaya, } \\
\text { Mizoram, Nagaland, Odisha, Sikkim, } \\
\text { Telengana, Uttarakhand, West } \\
\text { Bengal. }\end{array}$ \\
\hline $70-90$ & Semi-critical & 4 & 9 & 10 & 10 & $\begin{array}{l}\text { Himachal Pradesh, Tamilnadu, Uttar } \\
\text { Pradesh }\end{array}$ \\
\hline $90-100$ & Critical & 1 & 4 & 4 & 4 & Puducherry \\
\hline$>100$ & Overexploited & 3 & 14 & 14 & 15 & Punjab, Haryana, Rajasthan, Delhi \\
\hline
\end{tabular}

Source: Central Ground Water Board, 2011; Personal Computation

\begin{tabular}{|l|l|l|}
\hline Table 2: Number of States and Districts Affected by Major Contaminants, India, 2011 \\
\hline Contaminants & Number of Affected States & Number of Affected Districts \\
\hline Arsenic & 10 & 68 \\
\hline Fluoride & 20 & 276 \\
\hline Nitrate & 21 & 387 \\
\hline Iron & 24 & 297 \\
\hline
\end{tabular}

Source: Central Ground Water Board; PRS; Personal Computation

Groundwater concentration of fluoride depends on the nature of rock and solubility of fluoridebearing minerals, the contact time between rock and mineral with water circulation and climate of the region (Samal et al., 2015, Freckan,1992). High fluoride concentration in groundwater is found in the geo-geographical regions formed by igneous and metamorphic rocks in the form of granites and gneisses (Jha et al., 2013). According to Handa (1975), the genesis of high fluoride level in groundwater in India is generally associated with low calcium content, there being a negative correlation between the two ions, causing low solubility of fluorite. The deeper aquifer system indicates slow groundwater movement, ideal for the enrichment of fluorite into the water (Saxena and Ahmed, 2001 \& 2003).

Fluoride contamination in groundwater is geogenic in Genesis. But there are various artificial means too which intensify the concentration. Contamination of groundwater by organics, heavy metals, cyanide, aluminium and nitrates is anthropogenic in origin due to the uncontrolled discharge of effluents from the industries, sewage treatment plants and application of fertiliser and pesticides causing high fluoride level in groundwater (Rao, 2012 \& Pettenati et al., 2013).

Another vital reason for the enrichment of fluorine into groundwater as well as in the human body is the climatic factor (Rao, 2012). In the arid climate, evaporation concentrates fluoride in water (Weinstein and Davidson, 2004), whereas, in wet zone intense rainfall and long-term leaching of fluoride and other minerals from the crystalline bedrock are probably responsible for much lower concentrations (Edmunds \& Smedley, 1996). 
High fluoride concentration in groundwater is found in 29 countries around the world. The fluoride concentration in drinking water is 1.5 $\mathrm{mg} / \mathrm{l}$ (WHO, 2004; BIS, 2012). The fluoride in freshwater bodies such as rivers and lakes is generally less than $0.5 \mathrm{mg} / \mathrm{l}$, while, the fluoride content of seawater is as high as $1.0 \mathrm{mg} / \mathrm{l}$. In groundwater, however, the significant level of fluoride concentration occurs mainly in the areas where fluorine is found in great abundance in local sub-terranean minerals and rocks (Fawell et al., 2006).

Fluoride is an essential aspect of hydrogeochemistry of groundwater system as it imposes a severe impact on human health (Chakrabarti \& Ray, 2013). The severity of fluoride toxicity in humans depends upon both elemental concentrations in drinking water sources and exposure time and between fluoride concentration in water and exposure dose in different age-groups (Dregne, 1967 \& Viswanathan et al., 2009). Approximately, 200 million people from among 25 nations across the globe are suffering from fluorosis and India is one of the worst affected countries (Ayoob \& Gupta, 2006). Despite the potential risk of fluoride contamination in drinking water, fluorosis remains a serious and widespread health problem particularly among the rural communities (Chauh et al., 2016).

Of the estimated 85 million tonnes of fluoride stored in the ground globally, 12 million tonnes are expected to be in India (Teotia \& Teotia, 1984). The extent of fluoride contamination in water varies from 1 to $48 \mathrm{mg} / \mathrm{l}$ (Susheela, 2002). An estimate of 62 million people in 17 of the 32 states in India is affected by some form of fluorosis viz. dental, skeletal or non-skeletal fluorosis (Susheela, 1999). Of the 17 States, three - Rajasthan, Gujarat and Andhra Pradesh are highly endemic; nine -Punjab, Haryana, U.P., Bihar, Madhya Pradesh, Chhattisgarh, Jharkhand, Maharashtra, Karnataka and Tamil Nadu are moderately endemic; whereas, five Jammu \& Kashmir, West Bengal, Assam, Odisha and Kerala are under less endemic (RGNDWM, 1993). According to the CGWB (2013) about 276 districts in the country have reported high fluoride level in groundwater (Table 3). But current studies demonstrate that of 29 States in India, 20 have some extent of fluoride contamination in groundwater (Adimalla and Venkatayogi, 2017).

The number of villages and people endemic to fluorosis has steadily increased ever since the disease was discovered in India during the 1930s. In West Bengal, 43 blocks in 7 districts are profoundly affected by fluoride (above $1.5 \mathrm{mg} / \mathrm{l}$ ). The rural population of the state that remains at high risk is 7.408 million, which is about $11.91 \%$ of the total state of rural population (WBPHED, 2006). In West Bengal, fluoride contamination is reported from 60 blocks spread over eight districts (Chatterjee et al.,2008).

Puruliya district in West Bengal is the worst affected. In this district out of 20 blocks, 18 are profoundly affected by fluoride. The concentration varies from 0.126 to $8.16 \mathrm{ppm}$, and the worst affected blocks are Hura, PuruliyaI and Puruliya-II (Chackrabarti and Ray, 2013).

The fluoride problem has reached an alarming rate; however, the exact number of people facing the risk of exposure remains unknown due to lack of systematic survey and delineation of fluoride-affected areas (Jha et al., 2013).In this reference, the present paper focuses on mapping the spatial distribution of fluoride concentration with a focus on decadal change from 2005-06 to 2015-16 in Puruliya District, West Bengal. It attempts to highlight the status of fluoride concentration in groundwater vis- a`vis geographical locations and favourable conditions. An effort is made to estimate the population at risk in high fluoride exposed areas in Puruliya district and to suggest appropriate measures to mitigate the problem. The next section discusses the geographical location of the study area. 


\begin{tabular}{|c|c|c|c|}
\hline $\begin{array}{l}\text { Name of the } \\
\text { States }\end{array}$ & $\begin{array}{l}\text { No. Of } \\
\text { districts }\end{array}$ & Name of the Districts & $\begin{array}{l}\text { Range } \\
\text { of } \\
\text { Fluoride } \\
(\mathrm{mg} / \mathrm{l})\end{array}$ \\
\hline Rajasthan & 30 & $\begin{array}{l}\text { Ajmer, Alwar, Banswara, Barmer, Bharatpur, Bhilwara, Bikaner,Bundi, } \\
\text { Chhittorgarh, Churu, Dausa, Dholpur, Dungarpur,Ganganagar, } \\
\text { Hanumangarh, Jaipur, Jaisalmer, Jalore,Jhunjhunu, Jodhpur, Karauli, Kota, } \\
\text { Nagaur, Pali, Rajasamand,Sawai, Madhopur, Sikar, Sirohi, Tonk, Udaipur }\end{array}$ & $0.2-37.0$ \\
\hline Karnataka & 20 & $\begin{array}{l}\text { Bagalkot, Bangalore, Bellary, Belgaum, Bidar, Bijapur,Chamarajnagar, } \\
\text { Chikmagalur, Chitradurga, Devangere, Dharwar, Gadag, Gulbarga, Haveri, } \\
\text { Kolar, Koppala, Mandya,Mysore, Raichur, Tumkur. }\end{array}$ & $0.2-18.0$ \\
\hline $\begin{array}{l}\text { Andhra } \\
\text { Pradesh }\end{array}$ & 19 & $\begin{array}{l}\text { Adilabad, Anantpur, Chitoor, Guntur, Hyderabad,Karimnagar, Khammam, } \\
\text { Krishna, Kurnool, Mehboobnagar, Medak, Nalgonda, Nellore, Prakasham, } \\
\text { Rangareddy, Vishakhapatnam, Viziangaram, Warangal, West Godawari }\end{array}$ & $\begin{array}{l}0.11- \\
20.0\end{array}$ \\
\hline $\begin{array}{l}\text { Madhya } \\
\text { Pradesh }\end{array}$ & 19 & $\begin{array}{l}\text { Bhind, Chhatarpur, Chhindwara, Datia, Dewas, Dhar, Guna, Gwalior, } \\
\text { Harda, Jabalpur, Jhabua, Khargone, Mandsaur, Rajgarh, Satna, Seoni, } \\
\text { Shajapur, Sheopur, Sidhi. }\end{array}$ & $0.08-4.2$ \\
\hline Gujarat & 18 & $\begin{array}{l}\text { Ahmedabad, Amreli, Anand, Banaskantha, Bharuch, Bhavnagar, Dahod, } \\
\text { Junagarh, Kachchh, Mahesana, Narmada,Panchmahals, Patan, Rajkot, } \\
\text { Sabarkantha, Surat, Surendranagar, Vadodara }\end{array}$ & $\begin{array}{l}1.58- \\
31.0\end{array}$ \\
\hline Tamil Nadu & 17 & $\begin{array}{l}\text { Coimbatore, Dharmapuri, Dindigul ,Erode, Karur, Krishnagiri,Namakkal, } \\
\text { Perambalur, Puddukotai, Ramnathpuram, Salem, Shivaganga, Theni, } \\
\text { Thiruannamalai, Thiruchirapalli,Vellore,Virudunagar }\end{array}$ & $1.5-5.0$ \\
\hline Haryana & 14 & $\begin{array}{l}\text { Bhiwani, Faridabad, Gurgaon,Hissar, Jhajjar,Jind, Kaithal, Kurkshetra, } \\
\text { Mahendragarh, Panipat, Rewari,Rohtak, Sirsa,Sonepat }\end{array}$ & $\begin{array}{l}0.17- \\
24.7\end{array}$ \\
\hline Chhattisgarh & 12 & $\begin{array}{l}\text { Bastar, Bilaspur,Dantewara, Janjgir-Champa, Jashpur, Kanker,Korba, } \\
\text { Koriya, Mahasamund, Raipur, Rajnandgaon, Sarguja }\end{array}$ & $\begin{array}{l}0.18- \\
10.07\end{array}$ \\
\hline Orissa & 11 & $\begin{array}{l}\text { Angul, Balasore, Bargarh, Bhadrak, Boudh, Cuttack, Deogarh, Dhenkanal, } \\
\text { Jajpur, Keonjhar,Suvarnapur }\end{array}$ & $0.6-5.7$ \\
\hline Punjab & 11 & $\begin{array}{l}\text { Amritsar, Bhatinda, Faridkot,Fatehgarh Saheb, Firozpur,Gurdaspur, } \\
\text { Mansa,Moga, Muktsar, Patiala, Sangrur }\end{array}$ & $0.44-6.0$ \\
\hline Uttar Pradesh & 10 & $\begin{array}{l}\text { Agra, Aligarh, Etah, Firozabad, Jaunpur, Kannauj,Mahamayanagar, } \\
\text { Mainpuri, Mathura, Maunathbhanjan, }\end{array}$ & $0.12-8.9$ \\
\hline Bihar & 9 & $\begin{array}{l}\text { Aurangabad, Banka, Buxar, Jamui, Kaimur, Munger, Nawada,Rohtas, } \\
\text { Supaul }\end{array}$ & $0.6-8.0$ \\
\hline West Bengal & 8 & $\begin{array}{l}\text { Bankura,Bardhhman, Birbhum, Dakhin Dinajpur, Malda, Nadia,Purulia, } \\
\text { Uttar Dinajpur }\end{array}$ & $1.5-13.0$ \\
\hline Maharashtra & 8 & Amrwati, Chandrapur, Dhule, Gadchiroli,Gondia, Jalna, Nagpur,Nanded, & $\begin{array}{l}0.11- \\
10.2\end{array}$ \\
\hline Delhi & 6 & $\begin{array}{l}\text { East Delhi, New Delhi, Northwest Delhi, South Delhi, South-west Delhi, } \\
\text { West Delhi }\end{array}$ & $0.4-10.0$ \\
\hline Jharkhand & 6 & Bokaro, Giridih, Godda, Gumla,Palamau, Ranchi & $0.5-14.32$ \\
\hline Assam & 4 & Goalpara, Kamrup, Karbi Anglong, Naugaon & $0.2-18.1$ \\
\hline $\begin{array}{l}\text { Jammu } \\
\text { Kashmir }\end{array}$ & 2 & Rajauri, Udhampur & $\begin{array}{l}0.05- \\
4.21\end{array}$ \\
\hline Kerala & 1 & Palakkad & $0.2-2.5$ \\
\hline
\end{tabular}

Sources: Central Ground Water Board, 2013 and Personal Computation

\section{Location of the Study Area}

Puruliya district of West Bengal is located along the eastern slope of Chotanagpur plateau lying between $22^{\circ} 43^{\prime} \mathrm{N}$ to $23^{\circ} 42^{\prime} \mathrm{N}$ latitudes and $85^{\circ} 49^{\prime} \mathrm{E}$ to $88^{\circ} 54^{\prime} \mathrm{E}$ longitudes. The district covers a total area of $6259 \mathrm{sq} . \mathrm{Km}$ and is divided into 20 administrative blocks (Figure1). It is underlain by pre-Cambrian metamorphic rock 
except for a small area in the north-eastern part of the district where sediments of recent origin are found along the narrow river channels and valleys. The hard rock terrain, western location, passing of Tropic of Cancer makes it a droughtprone region where during hot summers existing surface water bodies get dried up, and groundwater becomes a significant source of water supply (CGWB, Purulia, 1989).

The drought condition further gets accentuated due to high evaporation loss, inadequate storage and lower moisture retention capacity of the soil. The absence of centrally treated water supply forces the people to use fluoride contaminated groundwater for drinking purpose. The situation gets worse due to the poor socio-economic condition of the people and the low level of education (Bhattacharya and Chakrabarty, 2011). People from many villages are detected with dental and skeletal fluorosis due to consumption fluoride contaminated water (Mondal \& Nath, 2015). The factors affecting the fluoride contamination are discussed in the next section.

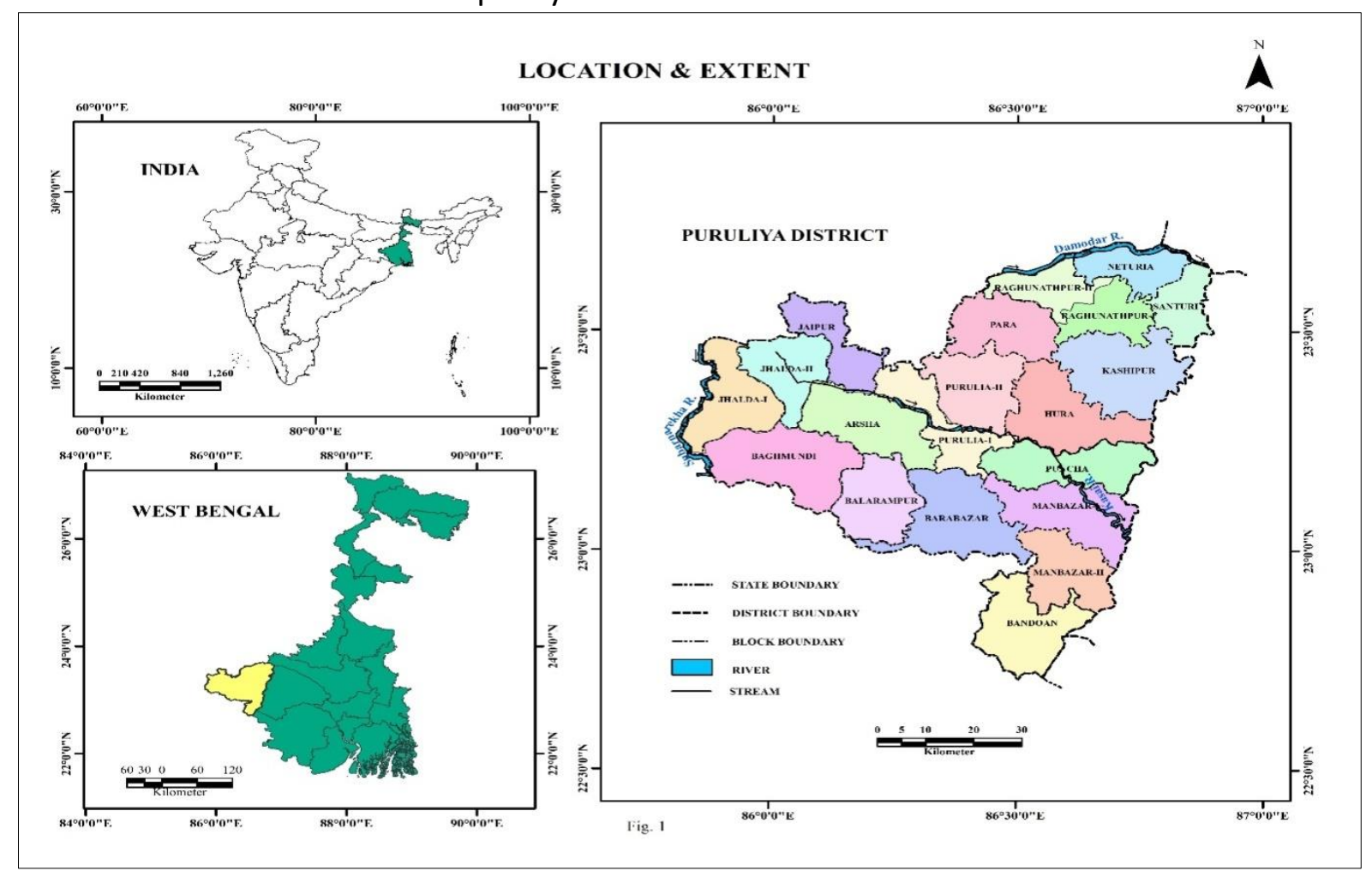

Figure 1: Location Map of the Study Area

Source: Authors

\section{Factors of Fluoride Enrichment in Groundwater, Puruliya District}

The area is primarily underlain by the preCambrian metamorphic rocks especially belonging to granite Gneiss (CGWB 1989) (Figure 2). Fluoride mineralisation is found to have been favoured by the presence of structurally weak planes like shear/fractured zones, joints and contact between host rocks and quartz veins. It is also to be noted that the hydro-geochemical characteristics of the sub-surface water also facilitates fluoride concentration.
High fluoride concentration is generally found in a deeper aquifer due to long residence time which favours prolonged rock-water interaction (Bhattacharya \& Chackrabarty, 2011). The maximum fluoride concentration is at a depth of 30 to $60 \mathrm{ft}$ below ground level in Puruliya district (Chakrabarty \& Ray, 2013). The shallow aquifers of weathered residuals and semi or unconfined aquifer of medium depth dug wells although consist lower levels of fluoride are prone to biological contamination and become dry during the summers (Mondal et al., 2013). Thus, during the dry season, a confined source of groundwater becomes the principal source of 
water supply which gets contaminated with high fluoride level.

The topographic features also play an essential role in the control of fluoride content (Rameshan and Rajagopalan, 1985). Alkalinity, evaporation and high bicarbonate content in the groundwater promote dissolution of fluorinerich minerals (Tirumalesh et al., 2007). Most of the fluoride regions are confined to arid and semi-arid zones (Ali, Thakur, Sarkar, \& Shekhar, 2016). In hot tropical parts of the world, people ingest more water and consequently the risk of $\mathrm{Fl}$ accumulation increases (Hussain et al., 2013). Moreover, in tropical countries, due to the hot weather, water intake is usually high in comparison to countries in the temperate regions.
According to Koppen's classification characterised by a dry tropical climate with hot summer and cold winter which falls under Aw type where health problems are more likely to occur due to the accumulation of high concentration of fluoride in drinking water (Jha et al., 2013). In the context of the study area, though $1288 \mathrm{~mm}$ of precipitation is received annually, due to undulating topography, variation in depth of soil and slope of the surface, runoff is high, and storage is less resulting into frequent drought occurrence in the entire district (Rudra, 2012). The higher rate of evaporation and low groundwater recharge also elevate the fluoride concentration in water. Excessive withdrawal of groundwater due to the scarcity of other freshwater sources exaggerates the problem. The methodological issues are outlined in the following section.

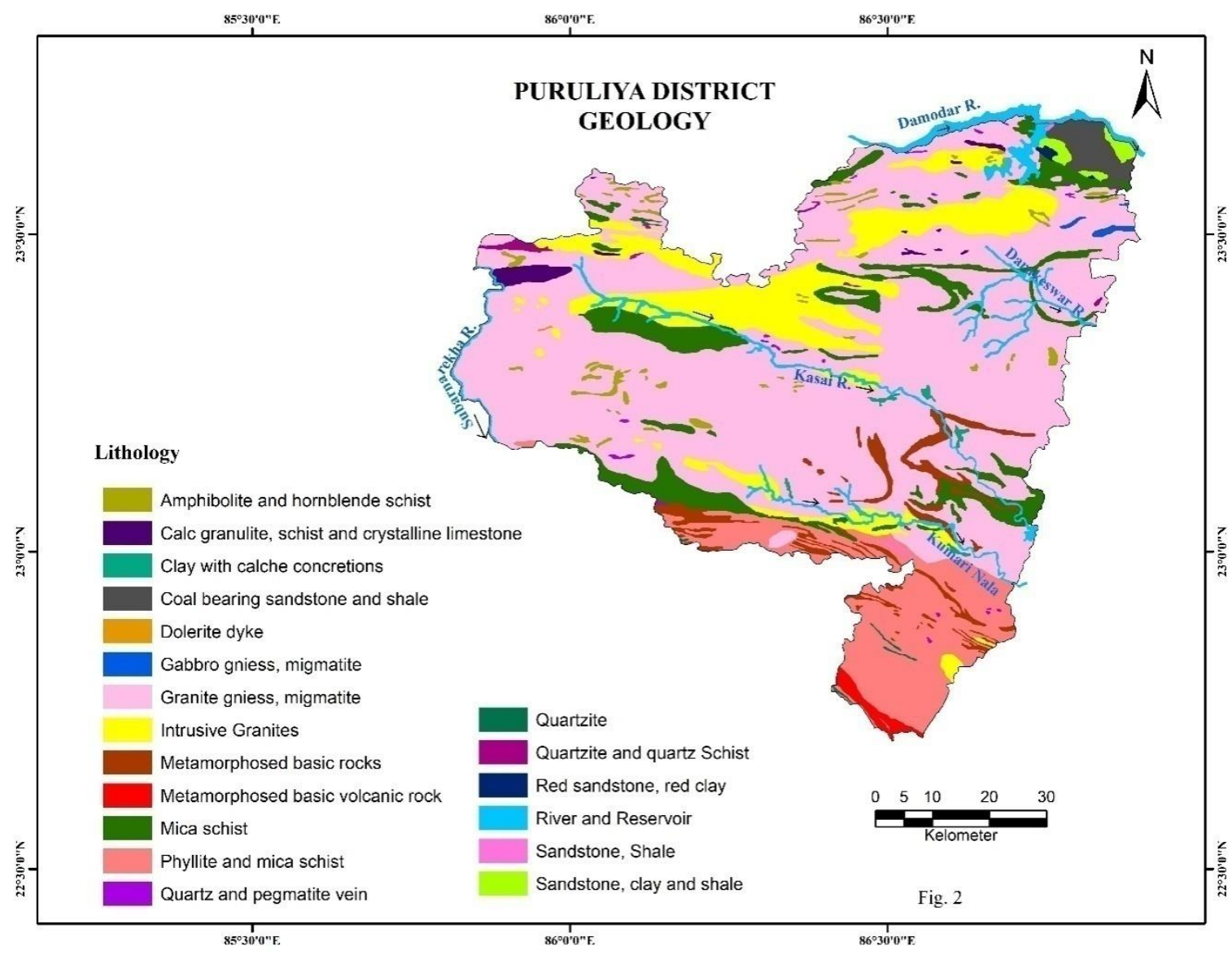

Figure 2

Source: Authors 


\section{Methodology}

The research is based mainly on secondary data collected from Physical Health \& Engineering Department (PHED), Puruliya and NRDWP (National Rural Drinking Water Programme) for fluoride concentration in groundwater for 200506 and 2015-16 in Puruliya district. The geological map (Figure 2) is a digitised version of the District Resource Map published by Geological Survey of India, Kolkata.

The pattern of fluoride contamination in groundwater in different blocks of Puruliya district is examined through the number of affected villages with fluoride above the threshold limit of $1.5 \mathrm{mg} / \mathrm{l}$. For this purpose, the maximum fluoride level for each village is considered. Blocks are categorised into three categories:

- as least affected (<10 per cent),

- moderately affected (10-20 per cent) and

- highly affected (> 20 per cent).

The representation of fluoride affected villages is prepared with the help of Arc.GIS. Further, to find out the population affected by high fluoride concentration in groundwater population, Census of India data -2001 and 2011 are used for the assessment period 2005-06 and 201516. The next few sections are devoted to discussing the results of the research in the study area.

\section{Results and Discussion}

\section{Distribution of Fluoride Concentration in Puruliya district}

Fluoride concentration in Puruliya district varies from 0.126 to $8.16 \mathrm{ppm}$ (WBPHED, 2006). During 2005-06, 17 out of 20 blocks were affected by high fluoride level in groundwater, beyond permissible limit of $1.5 \mathrm{mg} / \mathrm{l}$ (WHO 2004 \& BIS 2011) which increased to 18 blocks in 2015-16. Among the 17blocks, Hura, Puruliya-I, PuruliyaII, Raghunathpur-I, are the worst affected areas (Table 4).

The southern and south-eastern part of the district is comparatively less affected by fluoride. Bandoan, Jhalda-II, and Manbazar-II blocks have a fluoride concentration below $1.5 \mathrm{mg} / \mathrm{I}$ (WHO, 2004).

Tables 4 and 5 present the number of affected blocks during 2005-06 and 2015-16 under 5 different fluoride concentration range. In 200506, Raghunathpur-I block had the maximum percentage of affected villages bearing fluoride concentration of more than $1.5 \mathrm{mg} / \mathrm{l}$ while Santuri block recorded the least number of affected villages. The three blocks namely Bandoan, Jhalda-II, Manbazar-II had fluoride concentration of less than $1.5 \mathrm{mg} / \mathrm{l}$. Out of a total of 2468 villages in Puruliya district, 223 villages have fluoride level of more than $1.5 \mathrm{mg} / \mathrm{l}$. The maximum fluoride concentration $(8.16 \mathrm{mg} / \mathrm{l})$ is observed in the Kharai village of Kashipur block, although only 9.03 per cent of the villages have high fluoride concentration.

In some blocks, more than 25 per cent villages are affected by fluoride. Of the total of 223 affected villages in 17 blocks, 206 villages have fluoride concentration ranging from 1.5-3.5 $\mathrm{mg} / \mathrm{l}$; in 11 villages it ranges from $3.5-5.5 \mathrm{mg} / \mathrm{l}$; in 3 villages the range is between $5.5-7.5 \mathrm{mg} / \mathrm{l}$ and in 2 villages, the range is above $7.5 \mathrm{mg} / \mathrm{l}$. In 11 villages, the range of fluoride concentration is between $3.5-5.5 \mathrm{mg} / \mathrm{l}$ and these villages are from Para and Raghunathpur-I blocks (3 villages from each block). The other breakdowns are: two villages each from Hura and RaghunathpurII blocks and one village from Purulia-II block. Two villages each from Purulia-I and Jhalda-I have fluoride concentration ranging from 5.5-7.5 $\mathrm{mg} / \mathrm{l}$, whereas, Baghmundi and Kashipur block (1from each block) has maximum fluoride concentration above $7.5 \mathrm{mg} / \mathrm{l}$ (Figure 3).

Balarampur block has the maximum percentage of affected villages with fluoride concentration with more than $1.5 \mathrm{mg} / \mathrm{l}$ and Neturia block has the least amongst the total affected villages. The two blocks namely Bandoan and Manbazar-II have fluoride concentration of less than 1.5 $\mathrm{mg} / \mathrm{l}$. Out of a total of 2649 villages, 464 have fluoride level more than $1.5 \mathrm{mg} / \mathrm{l}$, and the rest of the 2184 villages have less than $1.5 \mathrm{mg} / \mathrm{l}$ or are within the permissible limit. Out of these 464 villages, 428 have fluoride concentration at a range of $1.5-3.5 \mathrm{mg} / \mathrm{l} ; 21$ villages have 
concentration in between $3.5-5.5 \mathrm{mg} / \mathrm{l}$ range, 11 villages within the range of $5.5-7.5 \mathrm{mg} / \mathrm{l}$ and 4 villages have fluoride concentration above 7.5 $\mathrm{mg} / \mathrm{l}$. Out of the 21 villages distributed in 8 blocks have fluoride concentration of 3.5-5.5 $\mathrm{mg} / \mathrm{l}$. These are five villages from Raghunathpur-
I block, three villages each from Para and Santuri, two villages each from Hura and RaghunathpurII block and one village each from Balarampur, Manbazar-I and Purulia-II blocks (Table 5 and Figure 3). Similarly, in 11 villages the fluoride concentration is about 5.5 to $7.5 \mathrm{mg} / \mathrm{l}$.

\begin{tabular}{|c|c|c|c|c|}
\hline \multirow[t]{2}{*}{ Range } & \multicolumn{2}{|r|}{ 2005-06 } & \multicolumn{2}{|r|}{ 2015-16 } \\
\hline & $\begin{array}{l}\text { No. of } \\
\text { Blocks }\end{array}$ & Name of Block & $\begin{array}{l}\text { No. of } \\
\text { Blocks }\end{array}$ & Name of Block \\
\hline$>1.5$ & 3 & $\begin{array}{l}\text { Bandoan, Jhalda-II, Manbazar- } \\
\text { II }\end{array}$ & 2 & Bandoan, Manbazar-II \\
\hline $\begin{array}{l}1.5- \\
3.5\end{array}$ & 17 & $\begin{array}{l}\text { Arsha, Baghmundi, } \\
\text { Balarampur, Barabazar, Hura, } \\
\text { Jaipur, Jhalda-I Kashipur, } \\
\text { Manbazar-I, Neturia, Para, } \\
\text { Puncha, Puruliya-I, Puruliya-II, } \\
\text { Raghunathpur-I, } \\
\text { Raghunathpur-II, Santuri }\end{array}$ & 18 & $\begin{array}{l}\text { Arsha, Baghmundi, } \\
\text { Balarampur, Barabazar, } \\
\text { Hura, Jaipur, Jhalda-I,Jhalda- } \\
\text { II, Kashipur, Manbazar-I, } \\
\text { Neturia, Para, Puncha, } \\
\text { Puruliya-I, Puruliya-II, } \\
\text { Raghunathpur-I, } \\
\text { Raghunathpur-II, Santuri } \\
\end{array}$ \\
\hline $\begin{array}{l}3.5- \\
5.5\end{array}$ & 5 & $\begin{array}{l}\text { Hura, Para, Puruliya-II, } \\
\text { Raghunathpur-I, } \\
\text { Raghunathpur-I, } \\
\text { Raghunathpur-II }\end{array}$ & 8 & $\begin{array}{l}\text { Balarampur, Hura, } \\
\text { Manbazar-I, Para, Puruliya- } \\
\text { II, Raghunathpur-I, } \\
\text { Raghunathpur-II, Santuri, }\end{array}$ \\
\hline $\begin{array}{l}5.5- \\
7.5\end{array}$ & 2 & Jhalda-I, Puruliya-I, & 8 & $\begin{array}{l}\text { Barabazar, Hura, Jaipur, } \\
\text { Jhalda-I, Puncha, Puruliya-I, } \\
\text { Raghunathpur-II, Santuri }\end{array}$ \\
\hline$<7.5$ & 2 & Baghmundi, Kashipur & 3 & $\begin{array}{l}\text { Baghmundi, Kashipur, } \\
\text { Santuri }\end{array}$ \\
\hline
\end{tabular}

These villages are from Jhalda-I, Purulia-I, Raghunathpur-I and Santuri blocks. In addition, 4 villages have fluoride concentration of above 7.5 $\mathrm{mg} / \mathrm{l}$ and these villages are from Kashipur, Baghmundi and Santuri blocks (Table 6).

In comparing the fluoride concentration levels of 2005-06 and 20015-16, the number of villages affected by fluoride has doubled from 223 to 464 , and the number of villages having fluoride level above $7.5 \mathrm{mg} / \mathrm{l}$ has comparatively increased. During, 2005-06, only 9.03 per cent villages were affected by fluoride which increased to 17.55 per cent by 2015-16. Interestingly, 62.22 per cent villages in Balarampur block are fluoride affected. Tables 2 and 3 show a significant change in fluoride level from 2005-06 and 20015-16 in Puruliya District (Figure 4).

The affected blocks are categorised into 3 classes based on the percentage of fluoride affected villages. These are-least affected $(<10$ per cent), moderately affected (10-20 per cent) and highly affected (>20 per cent) (Figure 4). Out of the 17 affected blocks, 11blocks are least affected, two blocks are moderately affected and four blocks are highly affected. Raghunathpur-I has the maximum percentage of fluoride affected villages while Santuri has the least number of affected villages. During 201516 , the number of affected blocks increased to 18. Out of 18 blocks, seven are highly affected, 
seven blocks moderately affected and four blocks are least affected.

Rural communities with non-centralised water supplies in the district are especially vulnerable to being exposed to fluoride contamination over a prolonged period, often because of the water being not tested for chemical contamination. Most of the municipalities and census town with large population, excessive irrigation practices, more number of tube-wells, over-application of fertiliser makes these blocks more prone to high fluoride effect. Further, a close view of the land use/land cover pattern, topography, slope, morphology of Puruliya district reveals various hidden factors behind uneven distribution of fluoride concentration in groundwater. The river beds, freshwater recharge points, downslope areas, forest covered areas have low fluoride concentration in their groundwater. Areas less developed or with a smaller number of tubewells, underuse of groundwater also results in low fluoride concentration in groundwater.

\begin{tabular}{|c|c|c|c|c|c|c|c|c|}
\hline \multirow[t]{2}{*}{ Block Name } & \multirow[t]{2}{*}{$\begin{array}{c}* \text { Total } \\
\text { Villages }\end{array}$} & \multicolumn{2}{|c|}{$\begin{array}{c}\text { Total Affected } \\
\text { Villages } \\
\text { (fluoride } \\
\text { concentration }>1.5 \\
\mathrm{mg} / \mathrm{l} \text { ) }\end{array}$} & \multicolumn{5}{|c|}{$\begin{array}{l}\text { Number of Range-wise Distribution of } \\
\text { Affected Villages }\end{array}$} \\
\hline & & (In no.) & $(\ln \%)$ & $<1.5$ & $1.5-3.5$ & $\begin{array}{l}3.5- \\
5.5\end{array}$ & $5.5-7.5$ & $>7.5$ \\
\hline Arsha & 95 & 6 & 6.31 & 89 & 6 & & & \\
\hline Baghmundi & 137 & 5 & 3.65 & 132 & 4 & & & 1 \\
\hline Balarampur & 90 & 6 & 6.66 & 84 & 6 & & & \\
\hline Bandoan & 132 & 0 & 0 & 132 & & & & \\
\hline Barabazar & 198 & 7 & 3.54 & 191 & 7 & & & \\
\hline Hura & 111 & 18 & 16.22 & 93 & 16 & 2 & & \\
\hline Jaipur & 110 & 18 & 16.36 & 92 & 18 & & & \\
\hline Jhalda-I & 132 & 3 & 2.27 & 129 & 2 & & 1 & \\
\hline Jhalda-II & 121 & 0 & 0 & 121 & & & & \\
\hline Kashipur & 199 & 17 & 8.54 & 182 & 16 & & & 1 \\
\hline Manbazar-I & 217 & 13 & 5.90 & 204 & 13 & & & \\
\hline Manbazar-II & 124 & 0 & 0 & 124 & & & & \\
\hline Neturia & 114 & 4 & 3.51 & 110 & 4 & & & \\
\hline Para & 119 & 24 & 20.17 & 97 & 21 & 3 & & \\
\hline Puncha & 98 & 9 & 9.18 & 89 & 9 & & & \\
\hline Purulia-I & 106 & 28 & 26.41 & 78 & 26 & & 2 & \\
\hline Purulia-II & 102 & 29 & 28.43 & 73 & 28 & 1 & & \\
\hline Raghunathpur-I & 80 & 24 & 30.00 & 56 & 21 & 3 & & \\
\hline $\begin{array}{l}\text { Raghunathpur- } \\
\text { II }\end{array}$ & 90 & 9 & 10.00 & 81 & 7 & 2 & & \\
\hline Santuri & 93 & 3 & 3.20 & 90 & 3 & & & \\
\hline Total & 2468 & 223 & 9.03 & 2247 & 206 & 11 & 3 & 2 \\
\hline
\end{tabular}




\begin{tabular}{|c|c|c|c|c|c|c|c|c|}
\hline \multirow[t]{2}{*}{ Block Name } & \multirow[t]{2}{*}{$\begin{array}{l}* \text { Total } \\
\text { Villages }\end{array}$} & \multicolumn{2}{|c|}{$\begin{array}{c}\text { Total Affected } \\
\text { Villages } \\
\text { (fluoride } \\
\text { concentration }>1.5 \\
\mathrm{mg} / \mathrm{l} \text { ) }\end{array}$} & \multicolumn{5}{|c|}{$\begin{array}{l}\text { Number of Range-wise Distribution of } \\
\text { Affected Villages }\end{array}$} \\
\hline & & (In no.) & $(\ln \%)$ & $<1.5$ & $1.5-3.5$ & $3.5-5.5$ & $5.5-7.5$ & $>7.5$ \\
\hline Arsha & 96 & 18 & 18.75 & 78 & 18 & & & \\
\hline Baghmundi & 141 & 6 & 4.25 & 135 & 5 & & & 1 \\
\hline Balarampur & 90 & 56 & 62.22 & 32 & 55 & 1 & & \\
\hline Bandoan & 134 & 0 & 0 & 134 & & & & \\
\hline Barabazar & 208 & 19 & 9.13 & 189 & 18 & & 1 & \\
\hline Hura & 116 & 21 & 18.10 & 95 & 18 & 2 & 1 & \\
\hline Jaipur & 110 & 20 & 18.18 & 90 & 19 & & 1 & \\
\hline Jhalda-I & 141 & 7 & 4.96 & 134 & 5 & & 2 & \\
\hline Jhalda-II & 130 & 18 & 13.85 & 112 & 18 & & & \\
\hline Kashipur & 205 & 29 & 14.15 & 176 & 27 & & & 2 \\
\hline Manbazar-I & 237 & 36 & 15.18 & 201 & 35 & 1 & & \\
\hline Manbazar-II & 133 & 0 & 0 & 133 & & & & \\
\hline Neturia & 125 & 4 & 3.2 & 121 & 4 & & & \\
\hline Para & 134 & 33 & 24.63 & 101 & 29 & 3 & & \\
\hline Puncha & 108 & 48 & 44.44 & 60 & 47 & & 1 & \\
\hline Purulia-I & 115 & 37 & 32.17 & 78 & 35 & & 2 & \\
\hline Purulia-II & 115 & 37 & 32.17 & 78 & 36 & 1 & & \\
\hline Raghunathpur-I & 102 & 30 & 29.41 & 72 & 25 & 5 & & \\
\hline $\begin{array}{l}\text { Raghunathpur- } \\
\text { II }\end{array}$ & 105 & 12 & 11.43 & 93 & 8 & 2 & 2 & \\
\hline Santuri & 104 & 32 & 30.77 & 72 & 26 & 3 & 2 & 1 \\
\hline Total & 2649 & 464 & 17.55 & 2184 & 428 & 21 & 11 & 4 \\
\hline
\end{tabular}




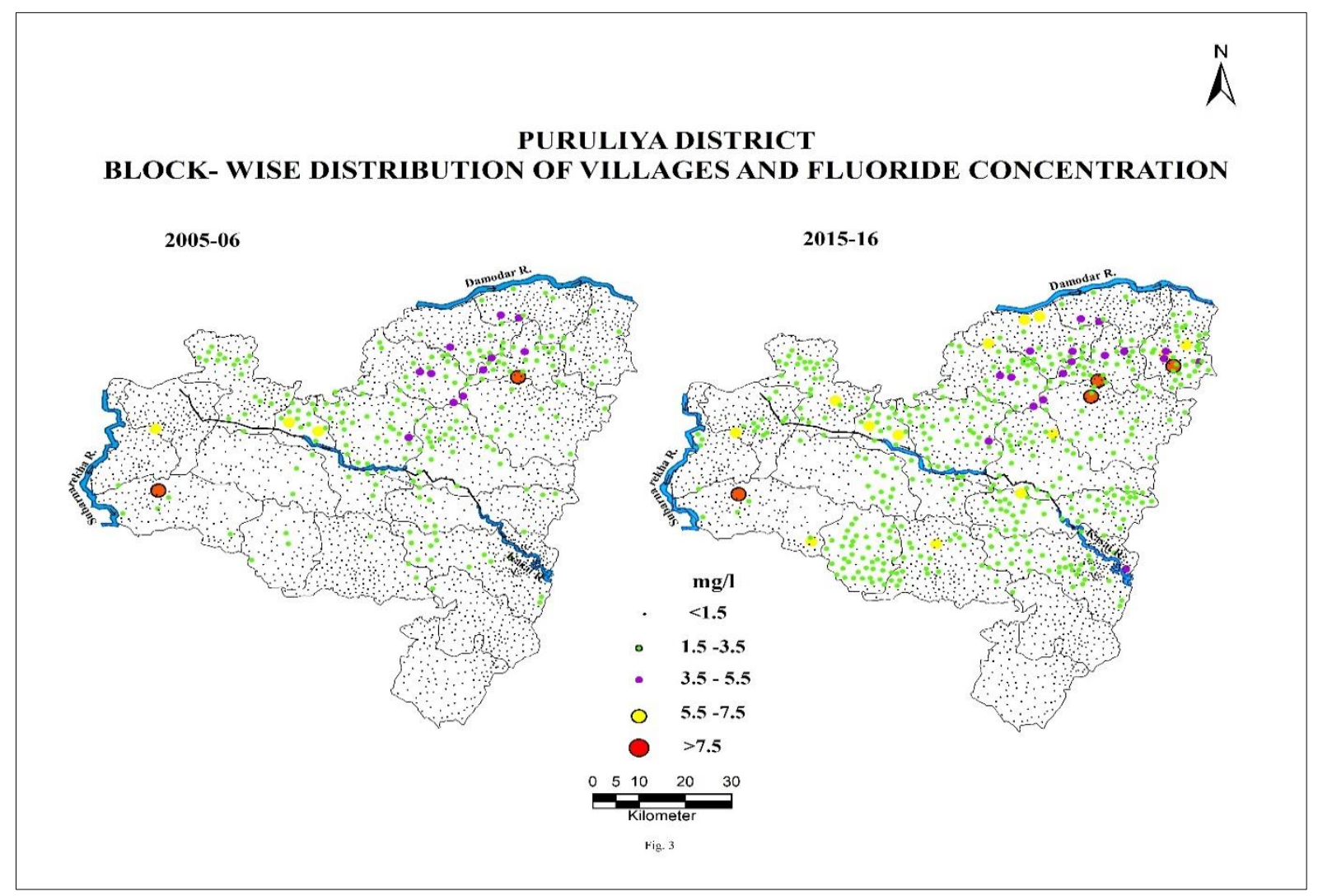

Figure 3

Source: Authors

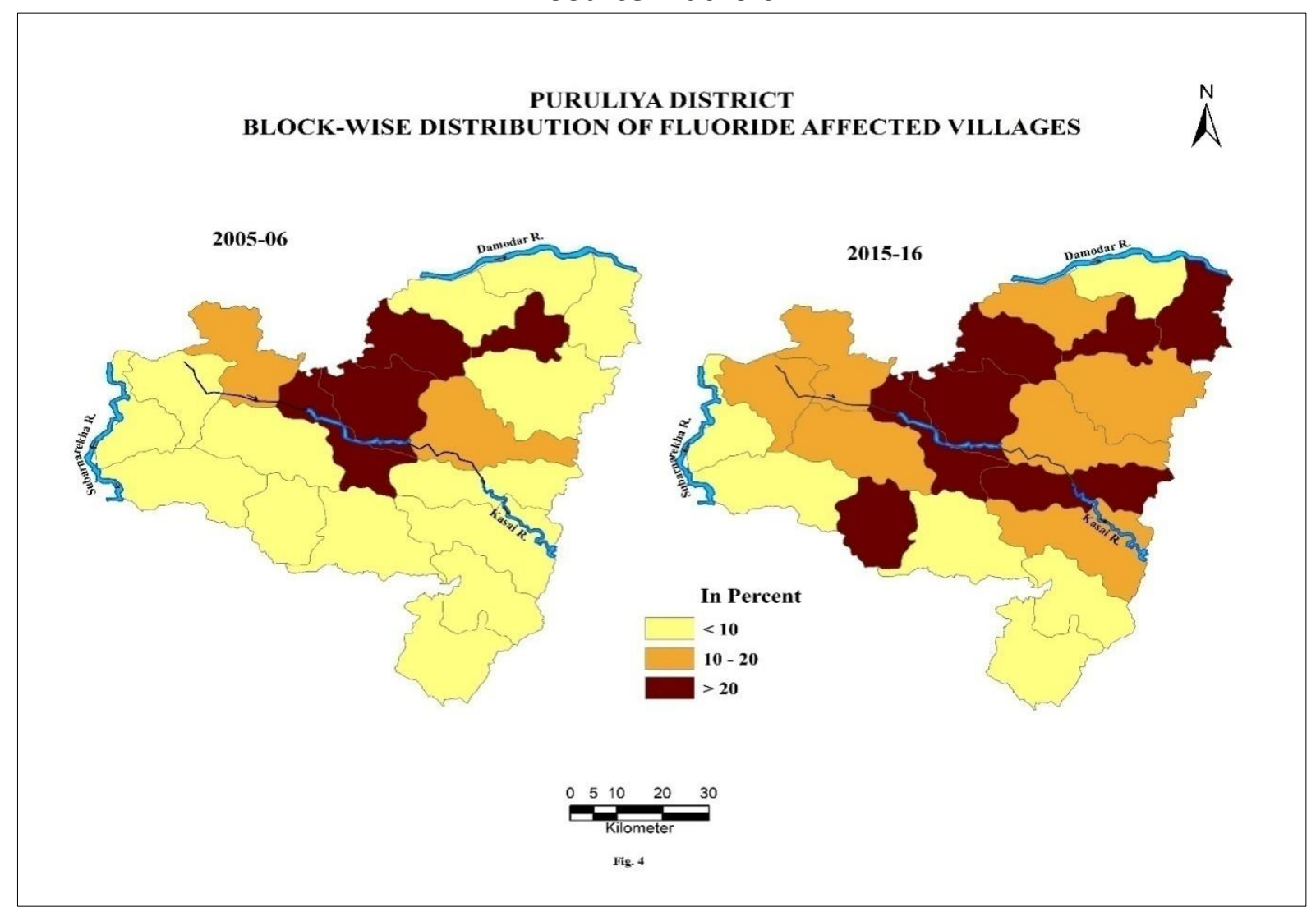

Figure 4

Source: Authors 


\begin{tabular}{|c|c|c|c|c|}
\hline \multirow{2}{*}{$\begin{array}{l}\text { **Fluoride } \\
\text { concentration } \\
(\mathrm{mg} / \mathrm{l})\end{array}$} & \multicolumn{2}{|c|}{$\begin{array}{l}* \text { No. of } \\
\text { villages }\end{array}$} & \multicolumn{2}{|c|}{$\begin{array}{l}\text { *No. of } \\
\text { population }\end{array}$} \\
\hline & $\begin{array}{l}200 \\
5- \\
06\end{array}$ & $\begin{array}{l}201 \\
5- \\
16\end{array}$ & $\begin{array}{l}2005- \\
06\end{array}$ & $\begin{array}{l}2015- \\
16\end{array}$ \\
\hline$<1.5$ & $\begin{array}{l}224 \\
5\end{array}$ & $\begin{array}{l}218 \\
6\end{array}$ & $\begin{array}{l}2,139 \\
503\end{array}$ & $\begin{array}{l}2,102, \\
055\end{array}$ \\
\hline $1.5-3.5$ & 206 & 428 & $\begin{array}{l}3,72,4 \\
36\end{array}$ & $\begin{array}{l}7,59,9 \\
51\end{array}$ \\
\hline $3.5-5.5$ & 12 & 21 & 12,217 & 23,399 \\
\hline $5.5-7.5$ & 3 & 11 & 11,656 & 42,194 \\
\hline$>7.5$ & 2 & 3 & 704 & 2516 \\
\hline Total & $\begin{array}{l}246 \\
8\end{array}$ & $\begin{array}{l}264 \\
9\end{array}$ & $\begin{array}{l}2,536, \\
516\end{array}$ & $\begin{array}{l}2,930, \\
115\end{array}$ \\
\hline
\end{tabular}

During the 2005-06, 15.65 per cent of the total population in Puruliya district were affected by fluorosis, which increased to 28.26 per cent by 2015-16 (Table 7). Population under risk in each range also shows much variation from 2005-06 to 2015-16. The affected people in the range of 1.5 to $3.5 \mathrm{mg} / \mathrm{l}$ were 14.68 per cent in 2005-06, which increased to 25.93 per cent in 2015-16. Similarly, the population rose from 0.48 per cent to 0.80 per cent in the range of 3.5 to $5.5 \mathrm{mg} / \mathrm{l}$, 0.46 to 1.44 per cent in range of 5.5 to $7.5 \mathrm{mg} / \mathrm{l}$ and 0.03 to 0.09 per cent with above $7.5 \mathrm{mg} / \mathrm{l}$ fluoride concentration in groundwater in 200506 and 2015-16 respectively. Overall, the study reveals that Raghunathpur-I, Para, Puruliya-I, Puruliya-II, Balarampur, Santuri are the worst affected blocks concerning population under risk.

Excess fluoride concentrations (>1.5 mg/L) can cause dental fluorosis (tooth discolouration, enamel pitting, early tooth loss) and skeletal fluorosis (joint stiffening and deformation) as well as a range of non-skeletal effects (Ozsvath, 2009). National Programme for Prevention and Control Fluorosis (NPPCF) observes that more than 45 per cent of children in primary schools in Puruliya district are affected by different forms of fluorosis (2014). Rainwater harvesting,

\section{Health Effect}

delineating safe fluoride aquifers, supply fluoride free safe drinking water, awareness among the public to check water quality regularly and promote public health programme can help to mitigate fluoride-related problems in Puruliya district.

\section{Conclusion}

The aim of the present research was to examine the concentration of fluoride and its impact on health in the Puruliya district of West Bengal. The key causes of fluoride concentration in the district are mainly due to geology, hydrology and climate factors. Anthropogenic factors like emissions from steel, aluminium, glass, and phosphate fertiliser, brick and tile industries, soil dust and crustal material, burning of coal and fly ash deposition also aggravates the situation.

The scarcity of surface water due to the long spell of drought, excessive withdrawal of groundwater due to increasing population, excessive use of groundwater for agriculture and industrial activities elevated the level of fluoride concentration in the district. Provision of safe drinking water supply is an effective way to reduce and eliminate fluorosis prevalence among the villagers. Further, socio-economic condition of the locals, tribal and ruraldominated demography, low education level, malnutrition, and lack of necessary health facilities and unchecked consumption of contaminated water elevated this problem in the district. This situation needs serious attention from both government and nongovernmental agencies. The study reveals that although Physical Health \& Engineering Department (PHED) of Puruliya are regularly collecting water sample to check water quality, there are shortages of personnel, instruments, chemicals, lack of implementation of defluoridation units which inhibits proper planning and management of the fluoride contamination. Therefore, it is essential to identify the geographical location of endemic fluoride areas to provide immediate health facilities and treatment to the population under risk of fluorosis at a block level. 


\section{References}

Adimalla, N., \& Venkatayogi, S. (2017) Mechanism of fluoride enrichment in groundwater of hard rock aquifers in Medak, Telangana State, South India. Environmental Earth Sciences, 76(1), pp. 45.

Ali, S., Thakur, S. K., Sarkar, A., \& Shekhar, S. (2016). Worldwide contamination of water by fluoride. Environmental chemistry letters, 14(3), pp. 291-315.

Agency for Toxic Substances and Disease Registry (ATSDR). (2001). Draft Toxicological Profile for Fluorine, Hydrogen Fluoride, and Fluorides. Atlanta, Georgia: U.S. Department Of Health And Human Services.

Ayoob, S., \& Gupta, A. K. (2006). Fluoride in drinking water: a review on the status and stress effects. Critical Reviews in Environmental Science and Technology, 36(6), pp. 433-487. Available online at:

http://www.tandfonline.com/loi/best20

[Accessed on 12 Sept 2016]

Bhattacharya, H. N., \& Chakrabarti, S. (2011). Incidence of fluoride in the groundwater of Purulia District, West Bengal: a geoenvironmental appraisal. Current Science, 101(2), pp. 152-155.

Census of India. (2011). District Census Handbook, Puruliya. Village and Town Wise Primary Census Abstract (PCA). Directorate of Census Operations West Bengal. Available at:

http://www.census2011.co.in/census/distri ct/13-Puruliya.html [Accessed on 10 April 2016]

Central Ground Water Board (1989). Groundwater resource development plan for the drought-prone Puruliya, Ministry of Water Resources, West Bengal.

Central Ground Water Board (2011). Dynamic Ground Water resources of India. Ministry of water Resources, River Development and Ganga Rejuvenation. India

Central Ground Water Board Report (2013). Name of the States/Districts from where chemical constituents in ground water beyond BIS Norms. Online available at http://cgwb.gov.in/contaminated- areas.html [Accessed on 15 September 2016]

Central Ground Water Board Report (2017). Ground Water scenario in India, Premonsoon. Ministry of Water Resources, River Development and Ganga Rejuvenation, India.

Chuah, C. J., Lye, H. R., Ziegler, A. D., Wood, S. H., Kongpun, C., \& Rajchagool, S. (2016). Fluoride: a naturally-occurring health hazard in drinking-water resources of Northern Thailand. Science of the Total Environment, 545, pp. 266-279.

Chakrabarti, S., \& Bhattacharya, H. N. (2013). Inferring the hydro-geochemistry of fluoride contamination in Bankura district, West Bengal: a case study. Journal of the Geological Society of India, 82(4), pp. 379391.

Chakrabarti, S., \& Ray, S. (2013). Fluoride contamination in a hard rock terrain: A case study of Purulia district, West Bengal, India. Journal of Chemical, Biological and Physical Sciences (JCBPS), 3(4), pp. 29-31.

Chatterjee, A., Roy, R. K., Ghosh, U. C., Pramanik, T., Kabi, S. P., \& Biswas, K. (2008). Fluoride in water in parts of Raniganj Coalfield, West Bengal. Current Science, 94(3), pp. 309-311.

Dregne, H. E. (1967). Water quality problems peculiar to arid regions. Symposium on Water Supplies for Arid Regions, Tucson, Arizona.

Edmunds, W. M., \& Smedley, P. L. (1996). Groundwater geochemistry and health: an overview. Geological Society, London, Special Publications, 113(1), pp. 91-105.

Frencken, J.E. (1992). Endemic Fluorosis in Developing Countries, Cause, Effects and Possible Solutions, Publication No. 91.082, NIPG-TNO, Leiden, the Netherlands.

Handa, B. K. (1975). Geochemistry and genesis of Fluoride-Containing ground waters in India. Groundwater, 13(3), pp. 275-281.

Hussain, J., Husain, I., \& Arif, M. (2013) Fluoride contamination in groundwater of central Rajasthan, India and its toxicity in rural habitats, Toxicological \& Environmental Chemistry, 95(6) pp. 1048-1055. 
Jha, S. K., Singh, R. K., Damodaran, T., Mishra, V. K., Sharma, D. K., \& Rai, D. (2013). Fluoride in Groundwater: Toxicological exposure and remedies. Journal of Toxicology and Environmental Health, Part B, 16(1), pp. 5266. Available online at https://www.tandfonline.com/doi/full/10.1 080/10937404.2013.769420?scroll=top\&ne edAccess=true [Accessed on 16 January, 2017]

Mason, J., \& Moore, L. C. (1982). A new way of investigating tubuloglomerular feedback: the closed-loop mode. Kidney international. Supplement, 12, pp. 151.

Mondal, D., Gupta, S., \& Mahato, A. (2013). Fluoride dynamics in the weathered mantle and the saprolitic zone of the Purulia district, West Bengal. Advances in Applied Science Research 4(6), pp.187-196.

Mondal, K., \& Nath, S. (2015). Fluoride Contamination on Aquatic organisms and human body at Purulia and Bankura District of West Bengal, India. Bulletin of Environment, Pharmacology and Life Sciences, 4, pp. 112-114.

National Programme for Prevention and Control of Fluorosis (NPPCF) Revised Guidelines (2014) online available at https://mohfw.gov.in/majorprogrammes/other-national-healthprogrammes/national-programmeprevention-and-control-fluorosis-nppcf. [Accessed on January 2016]

National Rural Drinking Water Programme (NRDWP, 2016). Contamination area wise report, Ministry of Drinking Water and Sanitation, Government of India. Available online at https://indiawater.gov.in/IMISReports/ [Accessed on 8 August 2017]

Ozsvath, D. L. (2009). Fluoride and environmental health: a review. Reviews in Environmental Science and Bio/Technology, 8(1), pp. 59-79.

Pettenati, M., Perrin, J., Pauwels, H., \& Ahmed, S. (2013). Simulating fluoride evolution in groundwater using a reactive multicomponent transient transport model: application to a crystalline aquifer of Southern India. Applied geochemistry, 29, pp. 102-116.

PHED (2006). Summary of Water Quality Status of the Spot Sources in the Fluoride Affected Blocks of West Bengal under the Joint Plan of Action with UNICEF as on March 2006. Public Health Engineering Department. Govt. of West Bengal, Kolkata. Available online at http://www.wbphed.gov.in/Static_pages/fl uoride.html [accessed on 8 August 2016]

PHED (2009). A note on fluoride contamination of groundwater in West Bengal. Public Health Engineering Department. Govt. of West Bengal, Kolkata. Available at www.wbphed. gov.in/flroride_cont.html. [Accessed on 2 March 2016]

Ramesan, V., and Rajagopalan, K. (1985). Fluoride ingestion into natural water of hard rock areas, Peninsular India. Geol. Oci. India, 126, pp. 125-135.

Rao, S.M., (2012). Influence of anthropogenic contamination on fluoride concentration in Groundwater. International Journal of Economics Environment and Geology. 3(1), pp. 24-33, online available at www.econenviron-geol.org [Accessed on 15 July 2016]

RGNDWM. (1993). "Prevention \& Control of fluorosis in India." Water Quality and Defluoridation Techniques, Volume II, Published by Rajiv Gandhi National Drinking Water Mission, Ministry of Rural Development, New Delhi.

Rudra, S. (2012). Fluoride Contamination of Ground Water: A Geographical Analysis of Purulia-I Block of Purulia District, West Bengal, India. 10.13140/Rg.2.2.14537.95840.

Samal, A. C., Bhattacharya, P., Mallick, A., Ali, M., Pyne, J., Santra, S. C. (2015). A study to investigate fluoride contamination and fluoride exposure dose assessment in lateritic zones of West Bengal, India. Environmental Science pollution research, (22) pp.6220-6229.

Saxena, V.K. and Ahmed, S. (2001) Dissolution of fluoride in groundwater: A water-rock 
interaction study. Environmental Geology, 40(9), pp.1084-1087.

Saxena, V.K., and S. Ahmed. (2003) Inferring the Chemical Parameters for the Dissolution of Fluoride in Ground Water. Environmental Geology (43), pp. 731-736.

Standard committee report on Water resources (2016). Ministry Of Water Resources, River Development and Ganga Rejuvenation, Secretariat, L. O. K. S. (2016). New Delhi, India.

Standard, D. I. (2012). Bureau of Indian Standards. Drinking water - specification. New Delhi, India. Available at: http://wbpcb.gov.in. [Accessed on 4 March 2016]

Suhag, R. (2016). Overview of Ground water in India. PRS

Susheela, A. K. (1999). Fluorosis management programme in India. Current Science,77, pp.1250-1256.

Susheela, A. K. (2002). Fluorosis in Developing Countries: Remedial Measures and approaches. Proceedings of Indian National Science Academy (PINSA).68(5). pp. 389400.

Teotia, S. P., \& Teotia, M. (1984). Endemic fluorosis in India: a challenging national health problem. The Journal of the Association of Physicians of India, 32(4), pp. 347.

Tirumalesh, K., Shivanna, K., \& Jalihal, A. A. (2007). Isotope hydrochemical approach to understand fluoride release into groundwaters of Ilkal area, Bagalkot District, Karnataka, India. Hydrogeology Journal, 15(3), pp. 589-598.

Viswanathana, G., Jaswantha, A., Gopalakrishnanb, S., Sivailangoc, S. (2009).
Mapping of fluoride endemic areas and assessment of fluoride exposure. Science of The Total Environment (407), pp.1579-1589. Online at http://www.sciencedirect.com [Accessed on 10 July 2016]

World Bank (2010). Deep Wells and Prudence:

Towards Pragmatic Action for Addressing Ground water Overexploitation in India. Washington, USA.

Weinstein, L. H., \& Davison, A. (2004). Fluorides in the environment: effects on plants and animals. CABI Press. Cambridge, USA. [ISBN 085199683 3]

WHO (2004). Guidelines for drinking water quality ( $3^{\text {rd }}$ ed.). Geneva: World Health Organisation.

\section{Acknowledgements}

This research is a part of the doctoral research of the second author and funded by University Grant Commission, New Delhi. The authors are thankful to the anonymous reviewers for their valuable suggestion.

\section{About the Authors}

Juthika Mandal is research scholar in the Department of Geography, Banaras Hindu University. She is also UGC- Senior Research Fellow. Her area of specification is application of cartography, Remote Sensing and GIS in Environmental Problems and Health Geography. Srabani Sanyal is Associate Professor of Geography at Banaras Hindu University, Varanasi. Her research interests include Environmental and Urban studies. She has written extensively in her areas of interest and has number of papers to her credit. 